\title{
A typology of farm households for the Umutara Province in Rwanda
}

\author{
J. C. Bidogeza • P. B. M. Berentsen • J. De Graaff • \\ A. G. J. M. Oude Lansink
}

Received: 6 April 2009 / Accepted: 30 July 2009 /Published online: 11 August 2009

(C) The Author(s) 2009. This article is published with open access at Springerlink.com

\begin{abstract}
For nearly 30 years, technologies for more sustainable land use have been developed and promoted in Rwanda. However, these technologies have not been fully adopted. Keeping in mind that the farming population is not homogeneous with respect to socioeconomic variables, this paper typifies farm households in Umutara province based on socio-economic factors influencing the adoption of new technology. A multivariate analysis approach that combines Principal Component Analysis and Cluster Analysis allowed us to identify clearly five types of farm households and their socio-economic characteristics. The main differences between the five farm types relate to gender, age, education, risk perception, risk attitude, labour availability, land tenure and income. The five farm types are characterized by respectively having a female head (26\% of the farms), being a tenant (7\%), having a male and literate head (32\%), having an illiterate head with no off-farm activities (18\%), and being a large farm with livestock (17\%). The respective farm types appeared to have adopted different types of sustainable technologies to a limited extent. Female-headed households adopted the use of compost and green manure. Young male literate farmers were the only ones using chemical fertilizers. Illiterate and full-time farmers
\end{abstract}

J. C. Bidogeza $(\bowtie) \cdot$ P. B. M. Berentsen •

A. G. J. M. Oude Lansink

Business Economics Group/Wageningen University,

Wageningen, Netherlands

e-mail: jean-claude.bidogeza@wur.nl

J. De Graaff

Land Degradation and Development

Group/Wageningen University,

Wageningen, Netherlands applied fallow, manure and erosion control measures to maintain soil fertility. The use of improved livestock is adopted by large farms.

Keywords Rwanda · Farm household · Farm typology · Technology adoption $\cdot$ Multivariate analysis

\section{Introduction}

In Rwanda, the population density has risen rapidly over the last 3 decades and is now the highest in Africa, with an average of 380 people per $\mathrm{km}^{2}$ arable land. Rural densities of more than 700 people per $\mathrm{km}^{2}$ are no exception (Service National de Recensement 2005). Sustainable use of natural resources in the face of high population density is critically important, and, consequently, food insecurity is overwhelming for Rwanda. The increasing population pressure on land and water resources leads to the degradation of these resources, which often results in the loss of productive capacity and food insecurity. Rwanda's farmers have responded to the pressure on the use of land and the associated decline in productivity by expanding into the fragile bottomlands and steep slopes. This situation has led to the excessive exploitation of natural resources and increased soil loss due to erosion, and, along with it, declining soil fertility. Research conducted by Stoorvogel and Smaling (1990) revealed that Rwanda has one of the most severe nutrient depletion rates in Africa, with on average $-54 \mathrm{~kg} \mathrm{~N}$, $-20 \mathrm{kgP}_{2} \mathrm{O}_{5}$, and $-56 \mathrm{Kg} \mathrm{K}_{2} \mathrm{O} \mathrm{ha}^{-1}$ year $^{-1}$. Furthermore, the use of mineral fertilisers is very low $(0.4-0.5 \mathrm{Kg}$ arable $\mathrm{ha}^{-1}$ ) due to their high price, which is aggravated by the land-locked position of the country and the associated high transportation costs (Drechsel and Reck 
1998). As fertilizer use has hardly increased in the past 20 years (GoR 2002a) the figures on nutrient depletion of Stoorvogel and Smaling (1990) are still valid.

For nearly 30 years, research has focused on the development and promotion of low-cost technology, such as agroforestry, fast-growing nitrogen-fixing legumes, the inter-or relay-cropping of green manure, farmyard manure, composting, mulching systems and green manure combined with other fertilisers (Drechsel et al. 1996; Roose and Ndayizigiye 1997; Drechsel and Reck 1998). However, despite the positive effects of these technologies on nutrient supply, a reduction in soil loss, and an increase in crop yields, fodder and firewood production, their adoption has remained low (Drechsel et al. 1996). Raquet and Neumann (1995) concluded that according to the experiences of "Projet agro-pastoral" in southern Rwanda, the adoption of new technologies, such as green manure, to improve soil fertility has failed, presumably because new technologies have not matched the socio-economic circumstances of farm households. There is a tendency to assume homogeneity within the farming population, particularly with respect to socio-economic variables (Nkonya et al 1997). So far, no study has been undertaken in order to analyse the level of homogeneity of farm households from the perspective of the adoption of new technology.

It is known that the adoption of new technology may vary among farm households because of differences in socio-economic characteristics (De Graaff 1996; Leeson et al. 1999; Solano et al. 2000; Mahapatra and Mitchell 2001; Asfaw and Admassie 2004; Somda et al 2005; Milán et al. 2006). A farm typology study can be used to classify farm households based on socio-economic characteristics that may affect the adoption of new technology. Developing a typology constitutes an essential step in any realistic evaluation of the constraints and opportunities that exist within farm households (Timothy 1994). Typology studies can therefore be of great importance for exploring the factors that explain the adoption of new technology (Kostrowicki 1977; Mahapatra and Mitchell 2001). Multivariate statistical techniques allow us to create such typologies, particularly when an in-depth database is available. The combination of Principal Component Analysis for necessary reduction of the number of variables followed by Cluster Analysis to identify typical farm households has been applied before by Gebauer (1987); Jolly (1988); Hardiman et al. (1990); Solano et al. (2001); Köbrich et al. (2003); Usai et al. (2006), and Jansen et al. (2006). Both methods have proved to be useful but they have their drawbacks. Principal component Analysis leads to loss of information (Jolliffe 1986; Lattin et al. 2005) and Cluster Analysis has the difficulty of choosing the proper number of clusters (Alfenderfer and Blashfield 1984; Everitt 1993).
The objective of this paper is to distinguish several farm types in the former Umutara province that might be expected to exhibit different behaviour with regard to the adoption of technology, The focus of study is on socio-economic factors rather than socio-cultural factors as the latter show less variation. The different types of farm households identified should yield key information needed to understand and diagnose problems as well as identify opportunities for change with regard to the adoption of new technology. Moreover, the resulting farm types can be used subsequently in further research as a basis for building mathematical programming models that are representative, similar to those of Köbrich et al. (2003). For the purpose of this study, a new technology includes any agricultural practice or input that may increase productivity directly or indirectly and which was not yet generally used in the area of study.

The paper is structured as follows: section 2 gives an overview of the determinants affecting the adoption of new technologies, section 3 presents the materials and methods used and section 4 the results and discussion. Conclusions and policy implications are given in section 5 .

\section{Determinants of new technology adoption: a review of the literature}

The literature on the adoption of new technology is extensive and complex. Since the classic work of Griliches (1957) on the adoption of hybrid corn in the US, efforts to assess the determinants of the adoption of new technology have continued. Two major groups of paradigms have emerged to explain differences in the adoption of new technology: the economic paradigm and the innovation-diffusion paradigm. The economic paradigm posits that the asymmetrical distribution of resource endowments between farmers is the major determinant of differences in adoption behaviour (Adesina and Zinnah 1993). Upadhyay et al. (2003) distinguish two models within the economic paradigm, namely, the income and the utility models. The income model assumes that farmers are profit maximisers and that technology that increases net returns to farming firms will be adopted (Griliches 1957; Mansfield 1961). The strength of this approach lies in understanding the role played by one of the major factors that motivate or inhibit new technology, i.e. an increase in income. However, one of the major criticisms of this model is that it fails to recognise heterogeneity among farmer's preferences (Nowak 1987). The utility model asserts that producers make adoption decisions based on utility maximisation rather than profit maximisation (Caviglia and Kahn 2001). In this model, 
the producer responds to economic factors, such as income, as well as to non-economic factors, such as environmental quality and social benefits.

Many sociologists favour the innovation-diffusion paradigm and follow the earlier work of Rogers (1962), which has resulted in various concepts, including innovators (that is, early adopters), followers, and laggards. A farm household typology might help to recognise these different groups. This paradigm underlines the role of information, risk factors and the social position of the decision maker in the community. Suitability of technology is taken as a given, and the problem of technology adoption is reduced to communicating information on technology to the potential end users (Ruttan 1996).

There have been many studies which have examined the factors influencing the adoption of technology by farm households in the light of the economic and innovationdiffusion paradigms. Especially in less developed countries (LDCs), the adoption of new technology in agriculture has attracted considerable attention from economists because the majority of the population derives its livelihood from agricultural production and new technology seems to offer an opportunity to increase production and income substantially (Feder et al. 1985; IFAD 2006). Literature on technology adoption has frequently stressed the role of different factors, such as farm size, capital and labour availability (economic paradigm); education, risk perception and risk attitude, and land ownership (innovationdiffusion paradigm). The remainder of this section elaborates on these variables.

\section{Farm size}

Empirical studies have consistently shown farm size (that is, land area) to be significantly related to the adoption of new technology (Feder et al. 1985; Feder and Umali 1993; Nkonya et al. 1997). A relatively small farm size impedes an efficient use and adoption of certain types of irrigation equipment, such as pumps and tube wells (Pomp 1994). Nkonya et al. (1997) have demonstrated that farm size significantly and positively influences the adoption of improved maize seed in a study conducted in northern Tanzania. Jamison and Lau (1982) have established a positive relation between the adoption of fertilisers and farm size in a study of Thai farmers. However, there seems to be a limit to the positive relation between farm size and technology adoption. Sureshwaran et al. (1996) found that the adoption of soil improvement measures on upland farms in the Philippines increased with farm size up to one hectare, after which size was no longer significant.

Farm size can have different effects on the rate of adoption, depending on the characteristics of the technology and the institutional setting. If technology is subject to economies of scale, then large farms will achieve greater profits from innovations than small farms. Several theoretical models of technology adoption, reviewed by Feder et al. (1985), have revealed that high fixed costs reduce the tendency towards adoption by small farms, while large farms are identified as earlier adopters, as they have more flexibility in their decisionmaking, greater access to discretionary resources, more opportunities to test new technology and an enhanced ability to bear risks associated with early technology adoption (Nowak 1987; Nkonya et al. 1997; Amsalu and De Graaff 2007). Feder and O'Mara (1982) have noted that, in certain contexts, there may be a lower limit of farm size such that farms smaller than a certain threshold will not adopt new technology.

\section{Education}

Empirical evidence suggests a positive relation between education and the adoption of new technology (Ervin and Ervin 1982; Feder and Umali 1993; Mahapatra and Mitchell 2001; Asfaw and Admassie 2004; Tenge et al. 2004; Onu 2006; Rahman 2007). According to a review by Asfaw and Admassie (2004), fertiliser adoption is influenced more by institutional and educational factors than by economic ones. Moreover, in a study conducted in Ethiopia Asfaw and Admassie (2004) found that education is positively and significantly related to the use of improved wheat varieties but not significantly related to the probability of adopting improved wheat. Feder and Slade (1984) found that number of school years and score in a numeracy test of the head of a household were key variables in the ability of farmers to acquire information and, hence, to adopt new technology. Jamison and Moock (1984) found that the adoption of chemical fertiliser is positively correlated with number of school years of the head of household in Nepal. This is consistent with the work conduced in the highlands of Tanzania by Tenge et al. (2004), who found that $60 \%$ of heads of households with a secondary school education adopted soil and water conservation (SWC) measures as compared to only $23 \%$ of heads with no formal education. The model developed by Asfaw and Admassie (2004) suggests that the educational level of other adult household members has a stronger impact on fertiliser adoption than the educational level of the head of household. Therefore, the education of other household members should also be considered.

There is consensus that the accumulation of knowledge via education is an important factor for economic development (Asfaw and Admassie 2004). Educated people are expected to perform certain jobs and functions 
with higher efficiency and are also more likely to adopt new technologies in a short period of time (Jamison and Moock 1984; Upadhyay et al. 2003). Adoption studies have taken education as an important explanatory factor in household decision-making.

Risk perception and risk attitude

The scarcity of empirical studies on the relationship between risk and the adoption of new technology is due to difficulties in measuring and observing risk and uncertainty (Feder et al. 1985; Marra et al. 2003). Empirical attempts to investigate the roles of risk and uncertainty in adoption have been reviewed by Feder et al. (1985), Feder and Umali (1993) and Marra et al. (2003).

Gafsi and Roe (1979) have shown that in Tunisia, new domestically-developed crop varieties are received more favourably by farmers than unfamiliar imported varieties. A related hypothesis is that exposure to appropriate information through various communication channels reduces subjective uncertainty, as illustrated by O'Mara (1990) with regard to the effect of perceived risk of new varieties of grains on the adoption decisions of Mexican farmers. Feder and Umali (1993) underlined that riskaversion leads a decision maker to diversify in order to reduce income risk, particularly in the absence of economies of scale with respect to the area allocated to the new technology. Kebede et al. (1990) found a positive but non-significant effect of risk-aversion for Ethiopian farmers with regard to the adoption of pesticide and fertiliser technology, which may be due to rainfall irregularities or other unexplained factors.

Risk has been considered a major factor that determines the rate of adoption of new technology (Feder et al 1985; Kebede et al. 1990; Baidu-Forson 1999; Ghadim and Pannell 1999; Marra et al. 2003). New technology in most cases involves risks, as crop yields are more uncertain with an unfamiliar technology. Risk perception is an endogenous factor, and thus, the implications of risk in terms of farmer decisions may change if the perceptions of farmers change (Feder and O'Mara 1982). Perceptions of risk related to new technology diminish over time through the acquisition of experience and information (Feder and Umali 1993). A farmer's attitude towards risk and his/her perception of risk on the profitability of new technologies all influence adoption decisions (Ghadim and Pannell 1999).

Capital availability

The shortage of capital required to finance new agricultural technologies is a major constraint in the adoption of such technologies (Feder et al. 1985; Feder and Umali 1993; Mahapatra and Mitchell 2001). Capital can originate from a farmer's savings or from his/her credit (Feder et al. 1990).

Lack of access to cash or credit may constrain farmers from adopting technologies that require initial investments (Doss 2006). Sources of credit may include monetary institutions (either formal or informal), relatives, friends, and rich farmers. However, in many rural areas, credit markets do not function properly (Feder et al. 1990), thereby resulting in a lack of credit. However, it has also been argued that this lack of credit alone does not inhibit the adoption of new technology which is scale-neutral. The profitability of high-yielding crop varieties (HYVs) will induce even small farmers to mobilise the relatively small cash requirements for necessary inputs. Other studies have found that a lack of credit does significantly limit the adoption of HYV technology, even where fixed costs are not high. Off-farm income sources may be viewed as an alternative to overcome cash or credit constraints and may enable farmers to invest in new technology.

\section{Labour availability}

Shortages of family labour have been used to explain the non-adoption of HYVs in India; meanwhile, the higher rural labour supply has been associated with greater levels of adoption of labour-intensive rice varieties in Taiwan (Bos 1998). For example, ox cultivation technology is labour-saving, and thus, its adoption might be encouraged by labour shortage. However, HYV technology generally requires more labour inputs, and so labour shortages may prevent adoption.

Labour availability is another often mentioned variable affecting farmers' decisions about adopting new agricultural practices or inputs (Feder et al. 1985). Some new technologies are relatively labour-saving, while others are labour-intensive (Feder et al. 1985; Doss 2006). For example, a shortage of labour was found to be a constraint in the adoption of agroforestry in Java and Nigeria, while in Mexico, a serious shortage of labour motivated landowners to adopt new technologies (Van der Poel and Van Dijk 1987; Francis and Atta-krah 1989). When local labour markets are functioning properly, farmers can hire labour as needed. When these markets are not functional, households must supply their own labour for farm activities, and so they may choose not to adopt technologies that would require more labour at any specific time than the household can provide. Therefore, a farm household with a large number of active members is more likely to be in a position to test and then adopt potentially profitable new technology (Kebede et al. 1990; Ghadim and Pannell 1999). 


\section{Land ownership}

Many empirical studies have focused on the link between land ownership and access to credit, as ownership of land is often thought to be a prerequisite for obtaining credit. In Ethiopia, farmers must own at least 0.5 ha of maize fields to participate in the maize credit scheme (Doss 2006). Feder and Nishio (1999) have clearly established the difference in economic performance between titled and untitled farmers. Per unit of used land, titled farmers invest more in land, use more inputs and generate higher levels of output than untitled farmers. It is generally held that tenants of farmland are less likely to invest in conservation practices (Feder and Umali 1993). Tenge et al. (2004) have found that households with borrowed and rented land do not apply any SWC measures to their fields. However, Lee and Stewart (1983) found that tenants are more likely to use conservation tillage than full owners. In northern areas of Honduras, Neill and Lee (2001) have demonstrated that land ownership increases the likelihood of using soil protection measures in general and that land security is positively and significantly associated with hedgerow adoption in particular. Sakurai (2006) has shown that investment in water supply canals for rice cultivation is influenced by the security of land tenure in western Africa.

Several studies have argued that tenure arrangement may play an important role in adoption decisions, but the subject remains riddled with considerable controversy (Feder et al 1985; Neill and Lee 2001). The literature distinguishes two types of land use by farmers, namely, formal entitling or various informal usufructuary arrangements (Neill and Lee 2001). Land registration has been shown to enhance tenure security and land titles improve economic performance mostly by facilitating access to institutional credit (Feder and Nishio 1999). Furthermore, in the Imo State of Nigeria, insecurity of land tenure increases the risks for farmers and, therefore, may decrease their adoption of new technologies (Onu 2005).

\section{Materials and methods}

Area of study

Research for this study was conducted in Umutara, a former province, located in the northeast of Rwanda at $30^{\circ} 20^{\prime}$ eastern longitude and $1^{\circ} 20^{\prime}$ southern latitude with an altitude between 1,000 and $1,500 \mathrm{~m}$ (Fig. 1) and belonging almost entirely to the driest agro-climatic region in the country. Annual rainfall in the province ranges from $800-1,000 \mathrm{~mm}$ with a bimodal rainfall distribution. The temperature doesn't vary much throughout the year with an average of $20.0^{\circ} \mathrm{C}$. Umutara has an area of $4,312 \mathrm{~km}^{2}$.

Umutara has some 420,000 inhabitants of which $98 \%$ live in rural areas. Most of the population of Umutara is newly settled. After the genocide ended in 1994, many Rwandan refugees that had left in 1959 and 1973, after earlier clashes, returned from Tanzania and Uganda. They brought herds of cattle with them as Umutara was chosen for resettlement because of the abundance of potential grazing land. Many of these former refugees maintained trade links with acquaintances in neighbouring former host countries. In the context of Umutara, a household is principally defined as a nuclear family consisting of father, mother and children. In some households, relatives, particularly orphans who lost their parents during the genocide or from HIV, have been adopted into nuclear families. A study conducted by Mowo et al. (2006) in a small traditional area within Umutara reports an average size of household of 7 persons. Land holdings per household range from 0.25 to $2.0 \mathrm{ha}$. Land is generally owned by the farmer, while after his death, the widow becomes the land owner.

The main source of income is the sale of crop and livestock products. Additional sources include craft work, construction and masonry and casual labour to other farmers. Informal trade is an important source of income for the farm household. Households spend income on medical services, self-sustenance, clothing and leisure. The expenditures on leisure are higher for men than for women. A wide range of crops is grown mainly for subsistence purposes. Mixed cropping is common. The choice of crops is dictated by climatic conditions, the availability of market outlets and the ease of crop management. Maize, beans, cassava, and bananas are the most important crops. The use of inorganic fertilisers is rare due to their limited availability and high prices. Because of the importance of animal husbandry in the area, organic manure is used to a large extent to fertilise various crops (Mowo et al. 2006).

\section{Data collection}

In 2004 and 2005, data were collected in the Umutara province by the National Institute of Statistics of Rwanda, using a national agricultural farm survey. The farm survey covered two rainy seasons, the first season falling in the year 2004 (July-December) and the second one in the year 2005 (January-June). For the purpose of the survey, Umutara was divided into eight 


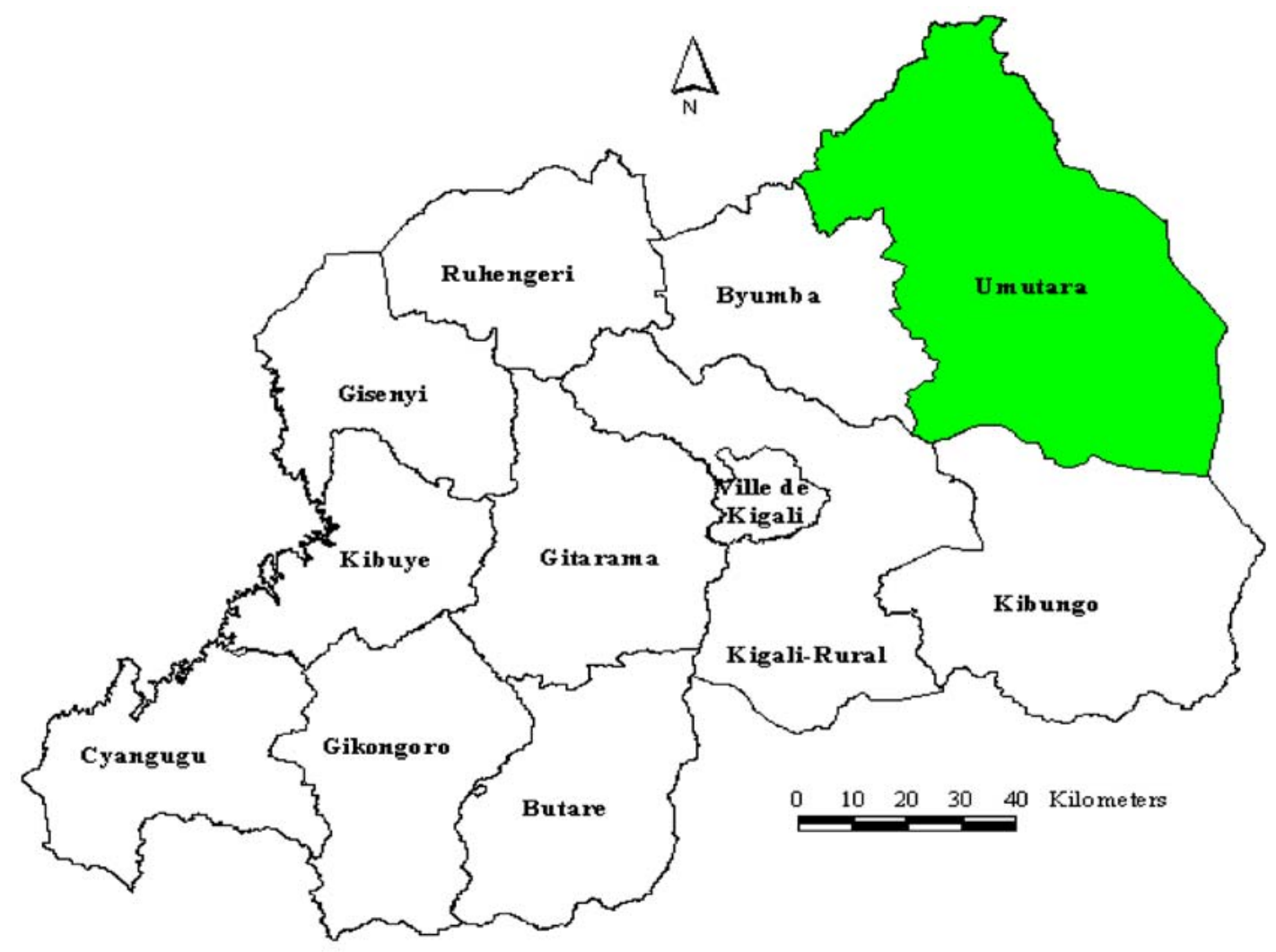

Fig. 1 Location of the Umutara province in Rwanda

census zones (zones de dénombrement), with 12 farm households randomly selected in each zone. Householdlevel data on the 96 households were recorded using a structured questionnaire. Both qualitative and quantitative information was collected on a total of 100 variables, including socio-economic characteristics, farm characteristics, resource availability and technological options. In addition, a small survey was conducted in 2006 using informal interviews on the characteristics of farm households, new technology adoption, production orientation, access to markets and credit, pricing and major constraints to farming. This latter survey provided more details and background information about farming in the region and it supports the results from the national farm survey (Bidogeza 2007).

On the basis of the review of the major factors influencing adoption of new technology (section 2), 23 variables were selected to construct a typology of farm households. The descriptive statistics of these variables are shown in Table 1.

Farm size (ha) is considered one of the most important factors in the adoption of new technologies. Households with small holdings may farm land more intensively to meet subsistence needs. Large farms may have a greater capacity to adopt new technology. Education is expressed as three variables, i.e., literacy of the head of household, education level of the head of household and the number of educated household members who have completed primary school. Literacy indicates the ability to write and to read, while level of education indicates whether primary school has been completed. Off-farm activities and crops per season are considered proxies for the risk perceptions and risk attitude of farm households. Off-farm activities may be viewed as a way to avoid risk and uncertainty associated with farming, while risk-averse farmers have a tendency to plant more crops to reduce risk. Source of income is expressed in terms of returns from crop and livestock and the number of household members working off-farm. Cash is required for initial investments in many new agricultural technologies. Labour availability is expressed in the number of on-farm household members.

The ownership variable distinguishes between farm households that own land and those that rent land. For a household, being headed by a male versus a female might affect the adoption of new technology as femaleheaded households have limited access to information on new technology and to other resources due to traditional social barriers (Tenge et al. 2004). The age of the household head might affect the adoption of new technology as young people have a long time horizon, 
Table 1 Descriptive statistics (mean and standard deviation) of the variables used in principal component analysis

\begin{tabular}{|c|c|c|c|}
\hline Name of variable & Description and units & Mean & Std. Deviation \\
\hline \multicolumn{4}{|l|}{ Farm size } \\
\hline Farm size & $=$ Farm size in $\mathrm{Ha}$ & 1.73 & 3.29 \\
\hline \multicolumn{4}{|l|}{ Education } \\
\hline Literacy of the head of Household & $=1$ if literate, 0 otherwise & .54 & .50 \\
\hline $\begin{array}{l}\text { Level of education of the head of } \\
\text { household }\end{array}$ & $=1$ if finished at least primary, 0 otherwise & .25 & .43 \\
\hline Educated family Member & $=$ Number of educated household members & .80 & 1.04 \\
\hline \multicolumn{4}{|l|}{ Risk perception and risk attitude } \\
\hline Off-farm activity & $\begin{array}{l}=1 \text { if head participates in off-farm activity, } \\
0 \text { otherwise }\end{array}$ & .55 & .49 \\
\hline Crops per season & $=$ Number of average crops per season & 5.64 & 1.85 \\
\hline \multicolumn{4}{|l|}{ Income } \\
\hline Returns per hectare & $\begin{array}{l}=\text { Total returns (crops \& livestock) per hectare in } \\
\text { thousands of Rwandese francs }\end{array}$ & 566.79 & 1266.05 \\
\hline Off-farm member & $\begin{array}{l}=\text { Number of off-farm household members working } \\
\text { outside of the farms }\end{array}$ & .79 & 1.00 \\
\hline \multicolumn{4}{|l|}{ Labour Availability } \\
\hline On-farm member & $=$ Number of on-farm household members working on the farms & 2.20 & 1.06 \\
\hline \multicolumn{4}{|l|}{ Land Ownership } \\
\hline Ownership & $=1$ ownership, 0 if otherwise & .93 & .24 \\
\hline \multicolumn{4}{|l|}{ Personal attributes of Head of Household } \\
\hline Gender & $=1$ if $\mathrm{HH}$ is male, 0 otherwise & .66 & .47 \\
\hline Age & $=$ Farmer' age in years & 43.34 & 16.91 \\
\hline Family size & $=$ Number of household members & 4.8 & 2.36 \\
\hline \multicolumn{4}{|l|}{ Technological Attributes } \\
\hline Fallow & $=1$ if applying, 0 otherwise & .43 & .49 \\
\hline Manure & $=1$ if applying, 0 otherwise & .31 & .46 \\
\hline Compost & $=1$ if applying, 0 otherwise & .30 & .46 \\
\hline Green manure & $=1$ if applying, 0 otherwise & .32 & .47 \\
\hline Mulching & $=1$ if applying, 0 otherwise & .28 & .45 \\
\hline Improved seed & $=$ Quantity of improved seed in Kilograms & 2.8 & 11.36 \\
\hline Fertilisers & $=$ Quantity of Chemical fertiliser in Kilograms or Litres & .21 & 1.57 \\
\hline Pesticides & $=$ Quantity of pesticide in kilogram or litre & .64 & 2.73 \\
\hline Improved livestock & $=$ Number of improved livestock & .23 & 1.58 \\
\hline Soil and water conservation measures & $=1$ if Applying SWC, 0 otherwise & .35 & .48 \\
\hline
\end{tabular}

which positively impacts investments in new technology, while older farmers with a lengthy experience in farming might be conservative, thereby favouring the continuation of traditional ways. Family size may positively affect adoption decisions by releasing labour needed for farming. Large families may encourage investments in new technology in order to produce enough food. Moreover, family size may affect the family income generated in off-farm work. However, large farm households may also be more risk averse (Oude Lansink et al. 2001) as they may have more dependent members, including young children and/ or physically disabled individuals.

The technologies considered in this study may be grouped into two categories. The first category includes technologies with low initial investment costs, such as fallow, manure, compost, green manure and mulching. These are coded as dummy variables that are allotted a value of 1 if the particular technology is applied by the farm household and 0 if it is not (Table 1). The selection of these technologies is motivated by their affordability and capacity to sustain land use. In the light of declining yields and lack of alternatives, Rwanda farmers, especially those with small households, still consider these technologies as options (Fleskens 2007). The second category includes technologies with high initial investment costs, such as improved crop varieties, mineral fertiliser, SWC measures and improved livestock. 
Multivariate statistical analysis

Farm household data were analysed and farm household typologies were constructed, using sequentially two multivariate statistical techniques, Principal Component Analysis (PCA) and Cluster Analysis (CA). PCA condenses all the information from the original interdependent variables to a smaller set of independent variables. Reduction of variables is a necessary first step as CA cannot deal with numbers of variables as high as those in Table 1 (Jolliffe 1986; Lewis-Beck 1993).

Prior to PCA, the dataset was checked for appropriateness of this technique. If the variables are largely independent or correlate very strongly, PCA may not be appropriate. Hence, the Kaiser-Maier-Olkin test (KMO) and Bartlett's sphericity test were performed to address this question (Lattin et al. 2005; Field 2005).

Variables selected were used to construct factors using PCA. Factors were rotated using orthogonal rotation (varimax method), whereby the method tries to load a smaller number of highly-correlated variables onto each factor, resulting in easier interpretation (Field 2005). In accordance with Kaiser's criterion, all factors exceeding an eigenvalue of one were retained. Kaiser's criterion is accurate when the number of variables is less than 30 (Field 2005), which is the case for our data set. This approach should allow a large part of the total information to be concentrated in a small number of uncorrelated variables.

Next, factors retained from PCA were used in CA. CA seeks to typify entities (that is, farm households) $M=(M 1, M 2, M 3 \ldots)$ according to their (dis)similarity in terms of their attributes represented by selected variables $\mathrm{N}=(N 1, N 2, N 3 \ldots)$ (Alfenderfer and Blashfield 1984; Gebauer 1987; Everitt 1993). Entities within a certain group or cluster should be very similar to each other, and entities belonging to different classes should be very dissimilar.

As no single objective procedure is available to determine the most suitable number of clusters, two clustering methods were used in order to ensure the stability of clusters, that is, the hierarchical method and the partitioning method (Hair et al. 2006). In the hierarchical method, the $k$-cluster solution is formed by joining together two clusters from the $k+1$ cluster solution, while the partitioning method separates the observations into a given number of clusters (Lattin et al. 2005 ).

Retained factors from PCA were used in CA using Ward's hierarchical procedure (Alfenderfer and Blashfield 1984). Ward's method minimises the variance within clusters and tends to find clusters of relatively equal sizes
(Kobrich et al. 2003). The numbers of clusters retained from Ward's method were used as starting values in the partitioning clustering method, i.e. the K-means method; accordingly, the number of clusters that seemed most realistic and meaningful was chosen for the final solution. Information from the dendogram, which results from the Ward's method, and expert knowledge of farming in the area (GoR 2002b) were employed to select an optimal number of clusters. A dendogram is a graphical representation of the hierarchy of nested cluster solutions. In addition to CA, a one-way analysis of variance test (that is, Levene's test) was performed. The test allows us to identify the differences in variance between clusters (Field 2005). Thus, the variables that bring about the largest differences between clusters could be identified.

\section{Results and discussion}

The KMO test and the Bartlett sphericity test were performed to check whether the dataset of 96 farm households and 23 variables could be factored. Results from both tests show that the overall KMO test was greater than 0.5 , which is the lower threshold (0.545), while Bartlett's sphericity test was highly significant $(p<0.001)$. Hence, the variables under study are related, justifying some form of factoring.

\section{Principal component analysis results}

In total, 23 variables were included in PCA (Table 1), of which 9 principal components with eigenvalues greater than 1 have been retained for further analysis (Table 2). These 9 variables explain $72 \%$ of the total variability. Looking at each column of Table 2, it is possible to define each component according to the variables with which it is most strongly associated. To make it easier to identify relatively large loadings, correlations above 0.4 are in bold. The first component (F1), which explains $12 \%$ of variance, is positively correlated with literacy, level of education and the number of educated family members. Thus, F1 represents the overall education level.

The second (F2) and third (F3) components are almost as important as the first component, each explaining $11 \%$ of variance. The second component is mostly related to family size, the number of educated family members and on-farm family members. This implies that farm households with large families are those that have more on-farm and educated family members. This component could be referred to as family size. The third component (F3) is strongly correlated with returns per hectare and the use of 
Table 2 Nine components resulting from principal components analysis with loadings for each of the 23 variables and percent cumulative variance explained

\begin{tabular}{|c|c|c|c|c|c|c|c|c|c|}
\hline \multirow[t]{2}{*}{ Name of Variables } & \multicolumn{9}{|c|}{ Component } \\
\hline & $\mathrm{F} 1$ & $\mathrm{~F} 2$ & F3 & $\mathrm{F} 4$ & F5 & F6 & F7 & F8 & F9 \\
\hline \multicolumn{10}{|l|}{ Farm size } \\
\hline Farm size & -.109 & .092 & -.206 & .348 & -.077 & .640 & -.163 & -.068 & .200 \\
\hline \multicolumn{10}{|l|}{ Education } \\
\hline Literacy of the head & .736 & -.243 & -.098 & .095 & .229 & .058 & .266 & .060 & -.149 \\
\hline Level of education of the head & .846 & .046 & -.030 & .077 & .049 & -.176 & -.098 & .001 & .103 \\
\hline Educated family member & .645 & .595 & -.072 & .029 & -.177 & .022 & .021 & .027 & -.021 \\
\hline \multicolumn{10}{|l|}{ Risk perception and risk attitude } \\
\hline Off-farm activity & .108 & -.115 & .073 & .843 & .076 & .101 & -.013 & .008 & .018 \\
\hline Crops per season & .099 & .088 & .013 & -.006 & .151 & -.634 & .502 & -.162 & .151 \\
\hline \multicolumn{10}{|l|}{ Income } \\
\hline Returns per hectare & -.034 & .011 & .940 & .041 & -.028 & -.020 & -.023 & .064 & -.070 \\
\hline Off-farm member & .169 & .290 & .210 & .738 & -.040 & .133 & .032 & .172 & .021 \\
\hline \multicolumn{10}{|l|}{ Labour availability } \\
\hline On-farm member & -.087 & .832 & .027 & .009 & .211 & -.073 & .028 & .075 & .059 \\
\hline \multicolumn{10}{|l|}{ Land ownership } \\
\hline Ownership & .071 & .021 & .011 & -.044 & .000 & .114 & -.004 & .088 & .832 \\
\hline \multicolumn{10}{|c|}{ Personal attributes of head of household } \\
\hline Gender & .177 & .018 & -.212 & .189 & .729 & .031 & .059 & .052 & .191 \\
\hline Age & -.311 & .449 & -.072 & -.191 & -.559 & .061 & -.168 & .131 & .067 \\
\hline Family size & .093 & .826 & .050 & .091 & -.049 & .323 & .042 & -.001 & -.013 \\
\hline \multicolumn{10}{|l|}{ Technological attributes } \\
\hline Fallow & .162 & .065 & .020 & -.189 & .133 & .041 & .756 & -.169 & -.051 \\
\hline Manure & -.245 & .062 & .063 & -.202 & .101 & .057 & .371 & .525 & .262 \\
\hline Compost & .239 & -.002 & .307 & -.444 & -.396 & -.051 & -.013 & .173 & .124 \\
\hline Green manure & .185 & -.043 & .015 & -.362 & -.189 & .104 & -.128 & .459 & -.537 \\
\hline Mulching & .432 & .189 & .149 & -.034 & -.141 & -.261 & -.103 & .501 & .144 \\
\hline Improved seed & .052 & .029 & .074 & .194 & .138 & -.018 & -.050 & .745 & -.060 \\
\hline Fertilisers & -.066 & .028 & .923 & .110 & .015 & -.036 & -.006 & .071 & .075 \\
\hline Pesticides & -.120 & -.049 & -.073 & .286 & -.091 & -.081 & .665 & .195 & .045 \\
\hline Improved livestock & -.045 & .167 & .053 & .030 & .112 & .726 & .148 & -.071 & .064 \\
\hline $\begin{array}{l}\text { Soil and water conservation } \\
\text { measures }\end{array}$ & -.133 & .216 & .224 & -.213 & .728 & -.011 & -.011 & .198 & -.059 \\
\hline Eigenvalues & 2.77 & 2.57 & 2.44 & 2.09 & 1.88 & 1.37 & 1.19 & 1.11 & 1.03 \\
\hline Cumulative explained variance & $12 \%$ & $23 \%$ & $34 \%$ & $43 \%$ & $51 \%$ & $57 \%$ & $62 \%$ & $67 \%$ & $72 \%$ \\
\hline
\end{tabular}

N.B. Bold numbers refer to loadings higher than 0.5

fertilisers. Hence, the adoption of mineral fertilisers results in high returns.

The fourth (F4) and fifth components (F5) explain 9\% and $8 \%$ of the variance, respectively. F4 is positively related to offfarm activities and family members off-farm. This component could be referred as to as off-farm activity. The fifth component is defined mainly by SWC measures with which the gender and age of the head of household are positively and negatively correlated, respectively i.e. households headed by young males are most likely to apply SWC measures.
The remaining four components each explain about 5\% of the variance. The sixth component (F6) shows a positive relationship between farm size and improved livestock and a negative relationship with the number of crops grown per season. In other words, large households own improved livestock and cultivate fewer crops per season. The seventh component (F7) shows a positive correlation of pesticides with respect to the number of crops per season and fallow, while the eighth (F8) component is positively correlated with manure, mulching, and improved seed. The ninth (F9) 
component shows a negative relationship between land tenure and use of green manure, as tenant farm households tend to use more green manure.

\section{Cluster analysis results}

First, the nine components were analysed using Ward's technique. The dendogram, resulting from this technique, illustrates the sequence in which farm households were merged into the clusters and includes four cutting lines (Fig. 2). A key issue in generating such diagrams is where to 'cut' the tree in order to arrive at an appropriate number of clusters which best fit the data set. Shifting the cutting line to the right (that is, from A to B in Fig. 2) reduces the number of clusters to nine. A further shift to the right, i.e., towards lines $\mathrm{C}$ and D, creates seven and five clusters, respectively. Cutting line A creates clusters that are generally not acceptable and should be eliminated as the number of their constituents is too small (Hair et al 2006). Thus, the numbers of clusters provided by cutting lines B, $\mathrm{C}$ and $\mathrm{D}$ (that is, nine, seven and five clusters, respectively) were drawn from the dendogram for use in the partitioning cluster method.

The number of retained clusters must be realistic with respect to the empirical situation in order to be accepted as a meaningful classification. Following that line of reasoning, nine clusters based on the partitioning method were defined as appropriate as these seem to be most representative of farm
Fig. 2 Dendogram with four possible cutting lines resulting from Ward's method of cluster analysis N.B.- Numbers on Yaxis express the identities of the farm households-Letters A, B, $\mathrm{C}$ and $\mathrm{D}$ show the cutting lines which give 14, 9, 7 and 5 clusters, respectively

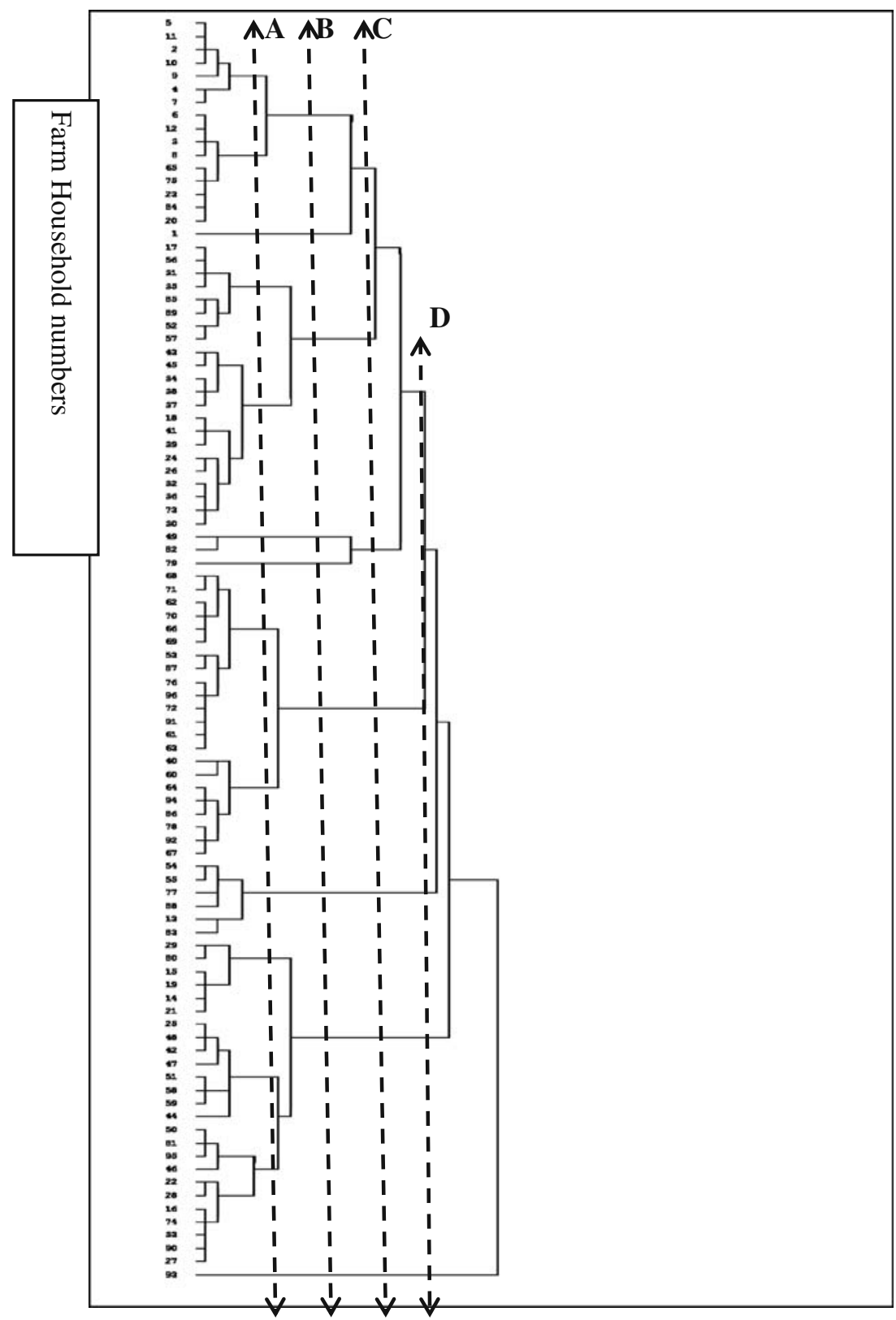


households within the Umutara province. They contained three single clusters and one paired cluster, which were discarded, as it was considered that these farms were too different from the rest of the sample and thus could be considered as outliers. Differences concerned high input levels of improved seed, fertilisers and pesticides.

The remaining five clusters appeared to represent the real situation based on information from our field work conducted from 2006. Results obtained from the five clusters are reported in Table 3, which shows the pvalues for a one-way analysis of variance for each variable (equality of group means). The more distinct a variable value is among groups, the lower is the p-value.

Given the established typology, we ask: what are the characteristics differentiating the five clusters? Judging from the p-values (Table 3), factors such as gender, age, literacy, level of education, off-farm activity, number of off-farm family members, tenure and farm size seem to be significant in differentiating the clusters. As this is also true for all technological attributes except pesticides (Table 3), this indicates that appropriate variables were chosen to construct this adoption-based typology.

Table 3 Characteristics of selected clusters of farm households and P-value of one way analysis of variance (equality of group mean)

\begin{tabular}{|c|c|c|c|c|c|c|c|c|}
\hline & $\begin{array}{l}\text { Cluster I } \\
N=24 \\
\text { Female } \\
\text { Headed }\end{array}$ & $\begin{array}{l}\text { Cluster } \\
\text { II } N=6 \\
\text { Tenant }\end{array}$ & $\begin{array}{l}\text { Cluster III } \\
N=28 \\
\text { Male\& } \\
\text { Literate }\end{array}$ & $\begin{array}{l}\text { Cluster IV } \\
N=17 \\
\text { Illiterate \& Full tim }\end{array}$ & $\begin{array}{l}\text { Cluster V } \\
N=16 \\
\text { Large \& } \\
\text { Livestock }\end{array}$ & $\begin{array}{l}\text { Cluster } \\
\text { Means }\end{array}$ & $\begin{array}{l}\text { Cluster Standard } \\
\text { Deviation }\end{array}$ & $\begin{array}{l}\mathrm{P}- \\
\text { Value }\end{array}$ \\
\hline \multicolumn{9}{|l|}{ Farm size } \\
\hline Farm size (ha) & 0.53 & 0.30 & 0.75 & 0.92 & 6.43 & 1.69 & 3.34 & 0.00 \\
\hline \multicolumn{9}{|l|}{ Education } \\
\hline Literacy of the Head & 0.5 & 0.66 & 0.96 & 0.11 & 0.25 & 0.53 & 0.50 & 0.00 \\
\hline $\begin{array}{l}\text { Level of Education } \\
\text { of the Head }\end{array}$ & 0.2 & 0.16 & 0.60 & 0.00 & 0.00 & 0.25 & 0.43 & 0.00 \\
\hline Educated family member & 0.66 & 0.66 & 1.17 & 0.52 & 0.62 & 0.79 & 1.05 & 0.44 \\
\hline \multicolumn{9}{|c|}{ Risk perception and risk attitude } \\
\hline Off farm activity & 0.33 & 0.50 & 0.71 & 0.17 & 0.93 & 0.53 & 0.50 & 0.00 \\
\hline Crops per season & 5.45 & 5.58 & $6 . .33$ & 6.17 & 4.2 & 5.6 & 1.88 & 0.71 \\
\hline \multicolumn{9}{|l|}{ Source of cash } \\
\hline Returns per hectare & 555.68 & 755.83 & 514.66 & 431.11 & 123.78 & 457.05 & 545.94 & 0.07 \\
\hline Off farm member & 0.41 & 0.50 & 0.92 & 0.17 & 1.43 & 0.71 & 0.92 & 0.05 \\
\hline \multicolumn{9}{|l|}{ Labour availability } \\
\hline On farm member & 1.5 & 1.8 & 2.1 & 3.2 & 2.2 & 2.17 & 1.07 & 0.09 \\
\hline \multicolumn{9}{|l|}{ Land tenure } \\
\hline Tenure & 1 & .00 & 1 & 1 & 1 & 0.93 & 0.24 & .00 \\
\hline \multicolumn{9}{|c|}{ Personal attributes of Head of Household } \\
\hline Gender & 0.16 & 0.5 & 1 & 0.8 & 0.6 & 0.65 & 0.47 & 0.00 \\
\hline Age & 48.9 & 41.5 & 31 & 48.2 & 52.6 & 43.4 & 17.2 & 0.08 \\
\hline Family size & 3.9 & 4 & 4.3 & 5.6 & 6.06 & 4.7 & 2.3 & 0.69 \\
\hline \multicolumn{9}{|l|}{ Technological Attributes } \\
\hline Fallow & 0.5 & 0.33 & 0.5 & 0.58 & 0.06 & 0.43 & 0.49 & 0.00 \\
\hline Manure & 0.37 & 0.16 & 0.1 & 0.58 & 0.18 & 0.28 & 0.45 & 0.00 \\
\hline Compost & 0.66 & 0.16 & 0.14 & 0.35 & .00 & 0.29 & 0.45 & 0.00 \\
\hline Green manure & 0.54 & 0.66 & 0.25 & 0.29 & 0.00 & 0.31 & 0.46 & 0.00 \\
\hline Mulching & 0.29 & 0.16 & 0.39 & 0.17 & 0.12 & 0.26 & 0.44 & 0.00 \\
\hline Improved seed & 1.87 & 0.00 & 1.5 & 0.58 & 0.00 & 1.06 & 4.17 & 0.03 \\
\hline Fertilisers & 0.00 & 0.00 & 0.17 & 0.05 & 0.00 & 0.06 & 0.38 & 0.00 \\
\hline Pesticides & 0.28 & 0.16 & 0.46 & 0.65 & 0.16 & 0.38 & 0.98 & 0.244 \\
\hline Improved livestock & 0.04 & 0.00 & 0.00 & 0.00 & 0.43 & 0.08 & 0.43 & 0.00 \\
\hline $\begin{array}{l}\text { Soil and water } \\
\text { conservation } \\
\text { measures }\end{array}$ & 0.41 & 0.33 & 0.46 & 0.82 & 0.00 & 0.32 & 0.47 & 0.00 \\
\hline
\end{tabular}


Cluster I, which accounts for $26 \%$ of farm households, is dissociated from the others due to its having the strongest discriminating power for the gender of the household head variable. Thus, cluster I comprises mainly households headed by females, i.e., either widows due to the genocide or natural death or those with husbands in prison due to suspected participation in the genocide. Furthermore, the cluster has relatively few off-farm activities but relatively high returns per hectare. In this cluster, we find above-average use of compost, green manure and improved seed. Adopting relatively cheap inputs such as compost and green manure as found in the cluster I, seems to endorse the findings of Kharwara et al. (1991) and Doss and Morris (2001), which demonstrate that constraints faced by female-headed households, such as low level of education and small farm size, prevent the adoption of costly technologies such as chemical fertilisers, which also require technical knowledge.

Cluster II comprises 7\% of farm households. The tenure variable has high discriminating power in distinguishing cluster II from other clusters. Farm households in this cluster are landless; rather, they are land tenants. Moreover, the cluster has the smallest farm size, with an average of 0.3 ha. However, high returns and high labour use per hectare are observed in this cluster. Farm households farm intensively with a relatively high use of green manure. Green manure is an effective way of improving soil fertility and it is a labour-intensive technology (Ndiaye and Sofranko 1994; Drechsel and Reck 1998). Thus, affordability and labour availability are reasons that farm households of this cluster adopted this technology, as the small area and the insecurity of land tenure prevent them from adopting other technologies. Overexploitation of land through high labour use and the low level of inputs (only green manure) could lead to the exhaustion of soil fertility, resulting in gradually declining returns per hectare.

For cluster III, which comprises $31 \%$ of farm households, the main distinguishing features include gender, age and education level of the household head. Farm households in this cluster are headed by young men (31 years old on average) with more education than those in other clusters. In these households, costly technologies, such as improved seeds and chemical fertilisers, have been adopted at a rate of adoption above the mean across clusters. Households headed by young, educated males are more likely to adopt new technologies, especially those that require information and an effective combination of inputs. Off-farm activities are also important, but they do not distinguish cluster III from clusters I, II, and IV. This could indicate that farm households classified in cluster III have relatively more economic options, which allows them to use capital-intensive technologies.

Cluster IV, which comprises $18 \%$ of households, represents farm households with a high level of illiteracy and little engagement in off-farm activities.
Moreover, these farm households are characterised by a relatively high labour to land ratio as compared to clusters I, III, and IV. Farm households farm with a relatively intensive use of fallow, manure and SWC measures. Thus, illiteracy and a lack of off-farm activities as a source of additional income prevent farm households from adopting costly technologies, such as improved seed, chemical fertilisers and improved livestock. The cluster shows the highest SWC measures, which suggest that the adoption of labour-demanding technology reflects the relatively high availability of labour in this cluster.

Cluster V includes $17 \%$ of farm households, and it is characterised by a large farm size, with an average of $6.43 \mathrm{ha}$, as well as a large number of household members working outside the farm. These farms have adopted improved livestock but almost no other technology.

It seems that farm households classified into this cluster have devoted their farm to pasturing. The returns per hectare in this cluster are lowest among all clusters; in fact, they are one-sixth of the returns per hectare of cluster II.

\section{Conclusions and policy implications}

A multivariate analysis approach that combines PCA and CA allows us to clearly identify five typical farm households within the Umutara province with respect to the adoption of new technology, using socio-economic factors. The data on 23 variables from 96 farm households were evaluated by multivariate statistical methods. Principal component analysis identified 9 factors that accounted for over $72 \%$ of variance in the original 23 variables. These nine factors were used in cluster analysis to typify farm households. Results from cluster analysis led to the identification of five farm types. The first type is characterised by female-headed households with a relatively high use of compost, green manure, and improved seeds. The second type represents tenants with small farms, high returns per hectare, and a relatively high degree of labour use per hectare. These farmers intensify farming through the use of green manure. The third type represents households headed by relatively young and literate males that intensively farm using chemical fertilisers and improved seeds. The fourth type represents illiterate and full-time farmers. The technologies they use most are fallow, manure, and SWC. The fifth type represents large farms with improved livestock, which have the lowest returns per hectare. The only technology adopted within this cluster is improved livestock.

Statistical testing showed that the discriminating power of most of the variables mentioned in section 2 and of the variables representing technology use is high. This indicates that the typology constructed can be useful to explore the adoption of new technologies. 
The low returns per hectare on the large farms of cluster $\mathrm{V}$ are in the line with several studies on Rwanda that report that some residents in the former Umutara province are acquiring land for the purpose of speculation rather than for agricultural production (Musahara and Huggins 2004; Pottier 2006). Given the much higher returns per hectare and the willingness to use low-cost technologies to maintain and improve soil fertility of the smaller farms, a policy to redistribute land in favour of smaller farms may address this situation.

The study has underlined the heterogeneity of farm households with regards to the current use and the determinants of future use of new technologies. As some types of farms have better possibilities for adopting technologies than others, extension messages and policies should be more focused on specific groups, such as these five farm types.

From this study, it can be concluded that multivariate statistical techniques such as PCA and CA are suitable tools for identifying important socio-economic characteristics of typical farm households that underlie the adoption of new technology. Differentiation of typical farms should help in the construction of mathematical programming models on the basis of typical farm households, which is the next step in terms of further research.

Acknowledgements The authors are grateful to three unknown reviewers and the editor who have greatly contributed to improvement of this paper.

Open Access This article is distributed under the terms of the Creative Commons Attribution Noncommercial License which permits any noncommercial use, distribution, and reproduction in any medium, provided the original author(s) and source are credited.

\section{References}

Adesina AA, Zinnah MM (1993) Technology characteristics, farmers perceptions and adoption decisions - a tobit-model application In Sierra-Leone. Agric Econ 9(4):297-311

Alfenderfer MS, Blashfield RK (1984) Cluster analysis. International Professional Publishers Berverly Hills, USA

Amsalu A, De Graaff J (2007) Determinants of adoption and continued use of stone terraces for soil and water conservation in an Ethiopian highland watershed. Ecol Econ 61(2-3):294-302

Asfaw A, Admassie A (2004) The role of education on the adoption of chemical fertiliser under different socioeconomic environments in Ethiopia. Agric Econ 30(3):215-228

Baidu-Forson J (1999) Factors influencing adoption of land-enhancing technology in the Sahel: lessons from a case study in Niger. Agric Econ 20(3):231-239

Bidogeza JC (2007) Internal report on supplementary farm survey. Umutara, Rwanda

Bos D (1998) Adoption process of a new potato variety, farmer's attitude towards potato variety 'BSU-PO3'. MSc Thesis Wageningen Agricultural University

Caviglia JL, Kahn JR (2001) Diffusion of sustainable agriculture in the Brazilian tropical rain forest: a discrete choice analysis. Econ Dev Cult Change 49(2):311-333
De Graaff J (1996) Price of soil erosion: an economic evaluation of soil conservation and watershed development. Mansholt studies 3. Backhuys, Leiden

Doss CR (2006) Analyzing technology adoption using microstudies: limitations, challenges, and opportunities for improvement. Agric Econ 34(3):207-219

Doss CR, Morris ML (2001) How does gender affect the adoption of agricultural innovations? The case of improved maize technology in Ghana. Agric Econ 25:27-39

Drechsel P, Reck B (1998) Composted shrub-prunings and other organic manures for smallholder farming systems in southern Rwanda. Agrofor Syst 39(1):1-12

Drechsel P, Steiner KG, Hagedorn F (1996) A review on the potential of improved fallows and green manure in Rwanda. Agrofor Syst 33(2):109-136

Ervin CA, Ervin DE (1982) Factors affecting the use of soil conservation practices - hypotheses, evidence, and policy implications. Land Econ 58(3):277-292

Everitt BS (1993) Cluster analysis, 3rd edn. Arnold, London

Feder G, Nishio A (1999) The benefits of land registration and titling: economic and social perspectives. Land Use Policy 15(1):25-43

Feder G, O’Mara GT (1982) On information and innovation diffusion: a bayesian approach. Am J Agric Econ 64(1)

Feder G, Slade R (1984) The acquisition of information and the adoption of new technology. Am J Agric Econ 66(3):312-320

Feder G, Umali DL (1993) The adoption of agricultural innovations-A review. Technol Forecast Soc Change 43(34):215-239

Feder G, Just RE, Zilberman D (1985) Adoption of agricultural innovations in developing-countries-A survey. Econ Dev Cult Change 33(2):255-298

Feder G, Lau LG, Lin JY, Xiaopeng L (1990) The Relationship between credit and productivity in chinese agriculture-A microeconomic model of disequilibrium. Am J Agric Econ 72(5):1151-1157

Field A (2005) Discovering statistics using SPSS: (and sex, drugs and rock ' $n$ ' roll). Sage, London

Fleskens L (2007) Prioritizing rural public works interventions in support of agricultural intensification. International center for soil fertility \& agricultural development (IFDC), Kigali

Francis PA, Atta-krah AN (1989) Sociological and ecological factors in technology adoption - fodder trees in southeast Nigeria. Exp Agric 25(1):1-10

Gafsi S, Roe T (1979) Adoption of unlike high-yielding wheatvarieties in Tunisia. Econ Dev Cult Change 28(1):119-133

Gebauer RH (1987) Socio-economic classification of farm households - conceptual, methodical and empirical considerations. Eur Rev Agric Econ 14:261-283

Ghadim AKA, Pannell DJ (1999) A conceptual framework of adoption of an agricultural innovation. Agric Econ 21(2):145-154

GoR (2002a) Rwanda: poverty reduction strategy paper. Ministry of Finance and Economic Planning, Kigali, Rwanda

GoR (2002b) Enquête intégrale sur les conditions de vie des ménages. Ministry of Finance and Economic Planning, Kigali, Rwanda

Griliches Z (1957) Hybrid corn - an exploration in the economics of technological-change. Econometrica 25(4):501-522

Hair JF, Black CW, Babin JB, Anderson ER, Tatham LR (2006) Multivariate data analysis. Pearson Prentice Hall, Upper Saddle River

Hardiman RT, Lacey R, Yang MY (1990) Use of cluster-analysis for identification and classification of farming systems in Qingyang County, Central North China. Agric Syst 33(2):115-125

IFAD (International Fund for Agricultural Development) (2006) Technical Advisory Notes: IFAD Agricultural Technologies for Rural Poverty Alleviation. http://www.ifad.org/lrkm/tans/5.htm. Accessed 28-April-2007

Jamison DT, Lau LJ (1982) Farmer education and farm efficiency. Johns Hopkings University Press, Baltimore 
Jamison DT, Moock PR (1984) Farmer education and farm efficiency in Nepal-the role of schooling, extension services, and cognitive skills. World Development 12(1):67-86

Jansen HGP, Pender J, Damon A, Wielemaker W, Schipper RA (2006) Policies for sustainable development in the hillside areas of Honduras: a quantitative livelihoods approach. Agric Econ 34 (2):141-153

Jolliffe IT (1986) Principal component analysis. Springer, University of Geneva, New-York

Jolly CM (1988) The Use of action variables in determining recommendation domains: grouping senegalese farmers for research and extension. Agric Adm Ext 30:253-267

Kebede Y, Gunjal K, Coffin G (1990) Adoption of new technologies in ethiopian agriculture: the case of Tgulet-Bulga District, Shoa Province. Agric Econ 4:27-43

Kharwara PC, Manchanda A, Kishwaria J, Kanwar P (1991) Comparative adoption of improved technology by female and male headed scheduled caste families. J Rural Dev 10(3):343-351

Kobrich C, Rehman T, Khan M (2003) Typification of farming systems for constructing representative farm models: two illustrations of the application of multi-variate analyses in Chile and Pakistan. Agric Syst 76(1):141-157

Kostrowicki J (1977) Agricultural typology concept and method. Agric Syst 2(1):33-45

Lattin J, Carroll D, Green P (2005) Analyzing multivariate data. 2nd Edition. Duxbury

Lee LK, Stewart WH (1983) Landownership and the adoption of minimum tillage. Am J Agric Econ 65(2):256-264

Leeson JY, Sheard JW, Thomas AG (1999) Multivariate classification of farming systems for use in integrated pest management studies. Can J Plant Sci 79(4):647-654

Lewis-Beck MS (1993) Factor analysis and related techniques. International handbooks of quantitative, applications in the social sciences 5 .

Mahapatra AK, Mitchell CP (2001) Classifying tree planters and non planters in a subsistence farming system using a discriminant analytical approach. Agrofor Syst 52(1):41-52

Mansfield E (1961) Innovation, size of firm, and market-structure. Econometrica 29(3):458-458

Marra M, Pannell DJ, Ghandim AA (2003) The economics of risk, uncertainty and learning in the adoption of new agricultural technologies: where are we on the learning curve? Agric Syst 75 (2-3):215-234

Milan MJ, Bartolome J, Quintanilla R, Garcia-Cachan MD, Espejo M, Herraiz PL, Sanchez-Recio JM, Piedrafita J (2006) Structural characterisation and typology of beef cattle farms of Spanish wooded rangelands (dehesas). Livest Sci 99(2-3):197-209

Mowo JG, Shem MN, Kanuya NL, Njeru R, Nyabahungu I (2006) Integrated watershed management: appropriate approach to natural resource management in Rwanda. Institut des Sciences Agronomiques du Rwanda, Kigali, Rwanda

Musahara H, Huggins C (2004) Land reform, land scarcity and post conflict reconstruction: a case study of Rwanda. Eco-Conflicts 3(3)

Ndiaye SM, Sofranko AJ (1994) Farmers perceptions of resource problems and adoption of conservation practices in A densely populated area. Agric Ecosyst Environ 48(1):35-47

Neill SP, Lee DR (2001) Explaining the adoption and disadoption of sustainable agriculture: The case of cover crops in northern Honduras. Econ Dev Cult Change 49(4):793-820

Nkonya E, Schroeder T, Norman D (1997) Factors affecting adoption of improved maize seed and fertiliser in northern Tanzania. J Agric Econ 48(1):1-12

Nowak PJ (1987) The Adoption of agricultural conservation technologies - economic and diffusion explanations. Rural Sociol 52(2):208-220

O'Mara GT (1990) MEXAGMKTS: a model of crop and livestock markets in Mexico. World Bank. Working Papers Series: no 446.
Onu DO (2005) Determinants of farm-level soil conservation and erosion control adoption and utilisation behaviours in the ecologically vulnerable areas of Imo State, Nigeria. J Rural Dev 24(4):521-544

Onu DO (2006) Socioeconomic factors influencing farmers' adoption of alley farming technology under intensified agriculture in Imo State, Nigeria. Philippine Agricultural Scientist 89(2):172-179

Oude Lansink AGJM, Verstegen JAAM, Van den Hengel JJ (2001) Investment decision making in Dutch greenhouse horticulture. Neth J Agric Sci 49(4):357-368

Pomp M (1994) Smallholders and innovation adoption. Ph.D. Dissertation, Free University, Amsterdam, Netherlands

Pottier J (2006) Land reform for peace? Rwanda's 2005 land law in context. J Agrarian Change 6(4):509-537

Rahman S (2007) Adoption of improved technologies by the pig farmers of Aizawl district of Mizoram, India. Livest Res Rural Dev 19(1)

Raquet K, Neumann IF (1995) Intensivbrache in der kleinbāuerlichen Landwirtschft.In: Egger K, Korus U (eds) Öko-Lanbau in den Tropen, pp 199-214. Müller Verlag, Heidelberg. In: Drechsel P, Steiner KG, Hagedon F (1996) A review on the potential of improved fallows and green manure in Rwanda. Agroforestry Systems 33:109-136

Rogers EM (1962) Diffusion of innovations. Collier-Macmillan, Canada

Roose E, Ndayizigiye F (1997) Agroforestry, water and soil fertility management to fight erosion in tropical mountains of Rwanda. Soil Technol 11(1):109-119

Ruttan VW (1996) Induced innovation and path dependence: A reassessment with respect to agricultural development and the environment. Technol Forecast Soc Change 53(1):41-59

Sakurai T (2006) Intensification of rainfed lowland rice production in West Africa: Present status and potential green revolution. Dev Econ 44(2):232-251

Service National de Recensement (2005) 3ème Recensement General de la Population et de l'Habitat du Rwanda au 15 Août 2002: Caractéristiques de la population par rapport à l'activité economique. Ministère des Finances et de la Planification Economique, Kigali

Solano C, León H, Péres E, Herrero M (2001) Characterizing objectives profiles of Costa Rican dairy farmers. Agricultural Systems 67:153-179

Solano C, Bernués A, Rojas F, Joaquin N, Fernandez W, Herrero M (2000) Relationships between management intensity and structural and social variables in dairy and dual-purpose systems in Santa Cruz, Bolivia. Agric Syst 65(3):159-177

Somda J, Kamuanga M et al (2005) Characteristics and economic viability of milk production in the smallholder farming systems in The Gambia. Agric Syst 85(1):42-58

Stoorvogel J, Smaling EMA (1990) Assessment of soil nutrient depletion in Sub-saharan Africa: 1983-2000. Vol.I. Main report, 2nded. Wageningen, The Winand Staring Centre, report 28, pp 137

Sureshwaran S, Londhe SR, Frazier P (1996) A logit model for evaluating farmer participation in soil conservation programs: Sloping agricultural land technology on upland farms in the Philippines. J Sustain Agric 7(4):57-69

Tenge A, De Graaff J, Hella JP (2004) Social and economic factors affecting the adoption of soil and water conservation in west Usambara highlands, Tanzania. Land Degrad Dev 15:99-114

Timothy WO (1994) Identifying target groups for livestock improvement research: The classification of sedentary livestock producers in western Niger. Agric Syst 46:227-237

Upadhyay BM, Young DL, Wang HH, Wandschneider P (2003) How do farmers who adopt multiple conservation practices differ from their neighbors? Am J Altern Agric 18(1):27-36

Usai MG, Casu S, Molle G, Decandia M, Ligios S, Carta A (2006) Using cluster analysis to characterize the goat farming system in Sardinia. Livest Sci 104(1-2):63-76

Van der Poel P, Van Dijk H (1987) Household economy and tree growing in upland central Java. Agrofor Syst 5(2):169-184 


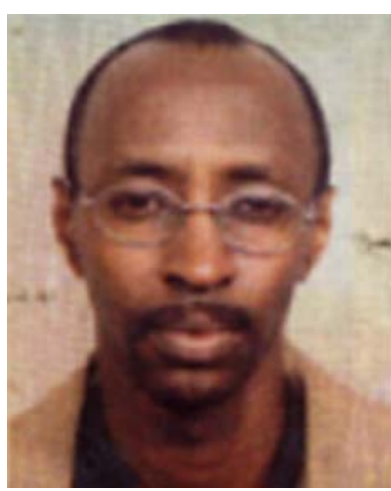

Jean-claude Bidogeza is $\mathrm{PhD}$ researcher at the Business Economics Group, Wageningen University. He holds a BSc in Agronomy (Ingénieur Agronome) from the University of Burundi and MSc in Management of Physical Land Resources from Ghent University and Free University of Brussels (Belgium). His $\mathrm{PhD}$ research is entitled: "Economic and Environmental Sustainable Farming to Ensure Food Security in Rwanda". Prior to starting his $\mathrm{PhD}$, he was a lecturer at the High Institute of Agriculture and Livestock in Rwanda.

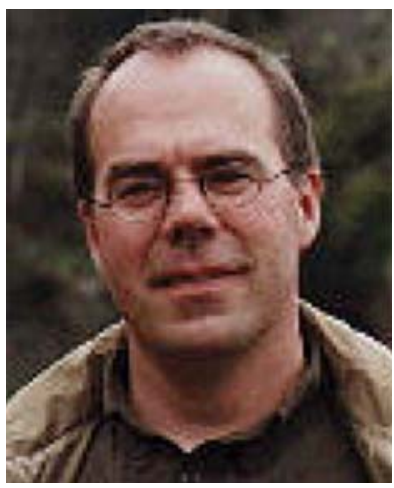

Paul Berentsen is lecturer and researcher at the Business Economics Group of Wageningen University. He holds a PhD (1999) and an MSc (1988) in Agricultural Economics from Wageningen University. $\mathrm{He}$ teaches courses in Farm Management and Mathematical Programming and he supervises MSc- and PhD-students. His research fields are animal production, environmental load, nature production, and Common Agricultural Policy. He is the editor of the peer-reviewed journal Agricultural Systems.

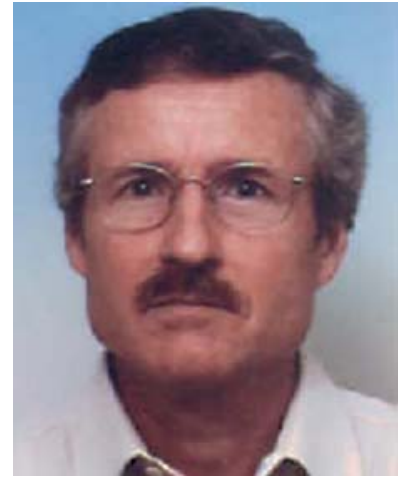

Jan de Graaff is senior lecturer with the Land Degradation and Development group of Wageningen University. He holds an Msc in Development Economics and his $\mathrm{PhD}$ Thesis (1996) was entitled "The price of soil erosion; the economics of soil conservation and watershed development". He worked for many years for the FAO and for the Royal Tropical Institute in several countries on economics of soil and water conservation, before joining Wageningen University. He is involved in lecturing on impact evaluation of land and water management in several EU and other research projects in southern Europe and Africa and he is the author of many articles and several books (e.g. on Economics of coffee).

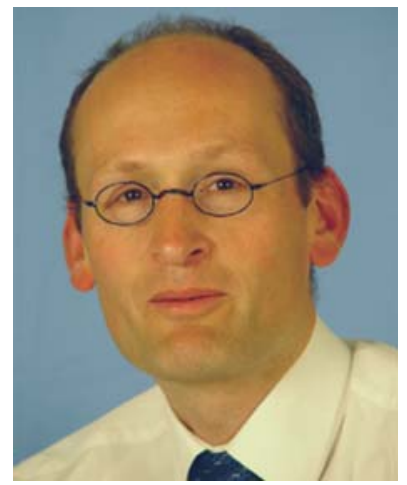

Alfons Oude Lansink is a Professor of Business Economics at Wageningen University. $\mathrm{He}$ holds a $\mathrm{PhD}$ in agricultural economics from Wageningen University. His main areas of research are micro-econometric modelling, efficiency and productivity analysis and economics of plant health. He is involved as a partner and workpackage leader in several EU projects and is a member of the scientific panel of plant health from the European Food Safety Agency (EFSA). Furthermore, he is member of the editorial board of the European Review of Agricultural Economics. 